\title{
Related variety and regional growth in Hungary: towards a transition economy approach
}

\begin{abstract}
The aim of this paper is to adapt related variety calculations to the special case of Hungarian regional development in the late post-socialist transition period. First, we test regional employment growth in rising and declining regions separately, in order to distinguish those areas that could cope with economic transition and those that could not. We find that related variety speeded up growth in the dynamic regions but at the same time pushed lagging regions to a downhill path that might be due to their unflexible industry structure. Second, regional variety measures are decomposed into domestic and foreign subsets and a new variable, ownership variety is introduced. Findings suggest that regional employment growth is due to related variety in the domestic set in earlier phases whereas the economy has evolved into a stage in which relatedness among foreign firms enhances regional employment growth significantly.
\end{abstract}

Keywords: related variety, regional employment growth, foreign-owned firms, postsocialist transition

\section{Introduction}

Co-location of companies are central concepts in the literature on regional economic growth. However, a fundamental debate has undermined the common understanding of regional employment growth in a region until recently: does regional specialization or diversity favours growth? Nevertheless, co-located companies from similar industries in industrial districts (Marshall 1890) or regional clusters (Porter 2003) are claimed to increase their productivity because they migth obtain very special and detailed knowledge from each other. On the other hand, companies co-located in economically diversified city-regions share and combine knowledge across industries more easily and therefore are more likely to create new variety and incremental innovation (Jacobs 1969; Glaeser et al. 1992). Thus, regional specialization and diversity might drive regional economic dynamics simultaneously, but on different basis.

A recent stream of literature claims that neither regional specialization nor regional diversity can provide efficient conditions for regional growth. Learning among very similar firms in a specialized region might not lead to growth, because the probability of

\footnotetext{
1 a Centre for Economic and Regional Studies, Hungarian Academy of Sciences, Budaörsi út 45, 1112 Budapest, Hungary b International Business School Budapest, Tárogató út 2-4, 1021 Budapest, Hungary, blengyel@gmail.com

c Faculty of Economics and Business Administration, University of Szeged, Kálvária sgt. 1, 6722 Szeged, Hungary, kano.izabella@eco.u-szeged.hu.
} 
obtaining new knowledge is low; on the contrary, firms have to share some knowledge in order to understand each other. Thus, a golden mean of technological proximity between co-located firms are needed in order that inter-firm learning provide ground for regional growth (Boschma 2005). This phenomena was first captured quantitatively by Frenken et al. (2007) by the formulation of related variety in a region, which builds on the concept of technological proximity and demonstrates that regional employment growth does not depent on diversity per se but the extent, to which industries are related to each other, is crucial.

The contribution of our paper is twofolds. First, we address the role of related variety in regional employment decline and growth in a post-socialist economy. Related variety might capture hidden characteristics of regional dynamics over economic transition, because previously prosperous industrial areas faced economic downturn and technological relatedness might have a special role in that. Second, we argue that additional proximity dimensions have to be involved in related variety calculations in order to understand regional economic growth in these areas. This latter step is important, because lagging firms may be isolated from the dynamic ones in terms of institutional or social conditions; thus not technological division but the lack of institutional or social proximity is what hinders inter-firm learning and regional growth.

Our demonstration is based on two distinctions. First, we analyse the role of related variety in rising and declining regions separately. Second, we decompose variety measures into domestic and foreign subsets. This latter step, namely the introduction of ownership categories into regional related variety calculations, requires an additional level of entropy decomposition and a new variable: ownership variety.

The findings suggest that related variety had a dual role in Hungarian regional development over the 1998-2005 period. It speeded up employment growth in those regions that could face the challenges of transformation. However, related variety had a negative effect on employment growth in declining regions, which suggests that technological relatedness pushed regions with uncompetitive industrial structure on a downhill path. We also find that regional employment growth is affected positively by related variety among the domestic set of firms initially but relatedness in the foreign subset started to contribute significantly to growth at a later stage.

The remainder of this paper is as follows. We give a brief overview from the Hungarian regional development in the post-socialist period, which is followed by the introduction of our data. The adaptation of related variety calculation to our special case is described in the fourth section. The fifth section gives an overview of results and discussion of findings as well as future research can be found the sixth section.

\section{Hungarian regional development}

The determining role of FDI, the remaining presence of some state-controlled services, and stagnating domestic companies have been the main features of transition economies in their current development model (Szanyi 2003). In the first half of the transition period, from 1990 to 1995, a massive economic downturn occurred in Hungary. Big state-owned companies either went bankrupt or got privatized; the latter was followed by basic restructuring. Consequently, unemployment rate, and especially long-term 
unemployment increased dramatically. MNEs started to carry out large investment projects in the tradable and services sectors (eg. automotive and ICT) and untraded sectors with secure local markets (eg. energy and communication) of Hungary. Simple, cheap unskilled labour-based activities were developed by additional investments (Iwasaki 2007).

Economic catching up started from year 1995, and employment rate approached again the level of year 1992 at the end of the period of our investigation. New, higher valueadded activities were launched, which utilized local skilled labour and engineering talent; some of the foreign companies started to locate their R\&D functions to their Hungarian sites (Lengyel-Cadil 2009).

The transition had a major footprint on regional development. Previously specialized industrial regions fell back quickly because they lost their market and became unable to meet the challenges of global competition (Lux 2009). Both regional specialization and spatial concentration of industries were proved to have a negative effect on regional employment growth (Lengyel-Szakálné 2013). Regional development is thought to be investment-driven, in which foreign direct investments have central role.

However, the role of foreign-owned firms in regional dynamics is still unclear. On the one hand, foreign-owned firms imported new knowledge to the economy, and many argue that this created positive spillover effects (Halpern-Muraközy 2007, Szanyi et al. 2011). On the other hand, domestic suppliers had only marginal roles in supplier networks of MNEs because their local decisions were usually determined by the parent company headquarters abroad (Grosz 2006). In many cases suppliers and competitors of these MNEs were mainly de-novo foreign firms that had followed their main partners into Hungary (Békés 2005). Thus, a dual structure of economy has evolved in Hungary, which can be characterised by a sharp foreign-domestic gap (Farkas 2000).

The dual economic structure and the gap between foreign-owned and domestic firms have had effected regional development as well. Those regions became relatively more competitive, in which foreign-owned companies invested (Lengyel 2003). However, foreign-owned firms have had positive effects in the relatively developed regions only and some argue that they have even destructed lagging regions (Lengyel-Leydesdorff 2011, 2013).

One might conclude that regional decline and catching up, the transition period itself, and the gap between foreign-owned and domestic companies created a unique field for testing the role of related variety in regional employment growth over post-socialist era. The current paper addresses two central questions:

1. What is the role of related variety in regional employment decline and growth?

2. How did domestic and foreign related variety affect regional employment growth?

\section{Data}

The information used for the empirical analysis in this paper was collected from the annual census-type data of Hungarian firms, which were compiled from financial statements associated with tax reporting submitted to the National Tax Authority in Hungary by legal entities using double-entry bookkeeping. The observation period covers 1998 and 2005 on a yearly basis. The data includes all industries and contains basic 
information for each sample firm, including the LAU1 region of company seats, NACE 4-digit industrial classification codes, the annual average number of employees, the amount of equity capital held by type of owners, and major financial indices at the end of the term.

Foreign ownership is attributed to a firm when $10 \%$ or more shares of the stocks of a firm are in foreign hands (HSCO 2007). This standard definition of the Hungarian Statistical Office considers a significant foreign interest in all of these firms even if domestic ownership is higher than foreign ownership in the firm.

All industries are present in the data, although for practical reasons we have excluded agriculture from the analysis and focus only on manufacturing and service sectors. One can find the distribution of firms along industry classifications according to 2-digit NACE categories in Appendix 1.

A major limitation of our data is that due to a change in company codes in year 2002, firms cannot be traced over the whole period. There is even a huge shift in terms of firm numbers across the two periods (Table 1). Although the data represents the total economically active population in a rather similar way (42\% in 1998 and $48 \%$ in 2002); the regional, sectoral, ownership distribution of firms might be very different across the two datasets. Therefore, we analyse regional employment growth in two distinct periods: 1998-2001 and 2002-2005.

Table 1

Employment and number of firms in our data

\begin{tabular}{l|r|r}
\hline & 1998 & \multicolumn{1}{|c}{2002} \\
\hline Employment in the data & $1,781,466$ & $2,092,942$ \\
Share in economically active population, \% & 42 & 48 \\
Domestic employment & $1,196,222$ & $1,563,175$ \\
Foreign employment & 585,244 & 529,767 \\
Number of firms & 112,075 & 298,031 \\
Number of domestic firms & 93,736 & 272,111 \\
Number of foreign firms & 18,339 & 25,920
\end{tabular}

Note: Economically active population was 4.263 million employees in 1998; and 4.298 million employees in 2002 http://www.ksh.hu/docs/eng/xstadat/xstadat_long/h_qli001.html

Despite company-level differences in the data, regional employment growth seems to be comparable across the two timeperiods under investigation. The average of employment growth across regions are around zero in both timesets; however, distributions differ. While the distribution of EMPGRO_9801 is close to be symmetric: Budapest $(-19,418)$ is the only outlier, the EMPGRO_0205 distribution is more skewed towards negative values (Figure 1a). The twoway association between the two variables depicts a medium strong correlation; employment growth in most of the regions deviate around zero (Figure 1b). 
Employment growth in regions, 1998-2001 and 2002-2005

Figure 1a, b

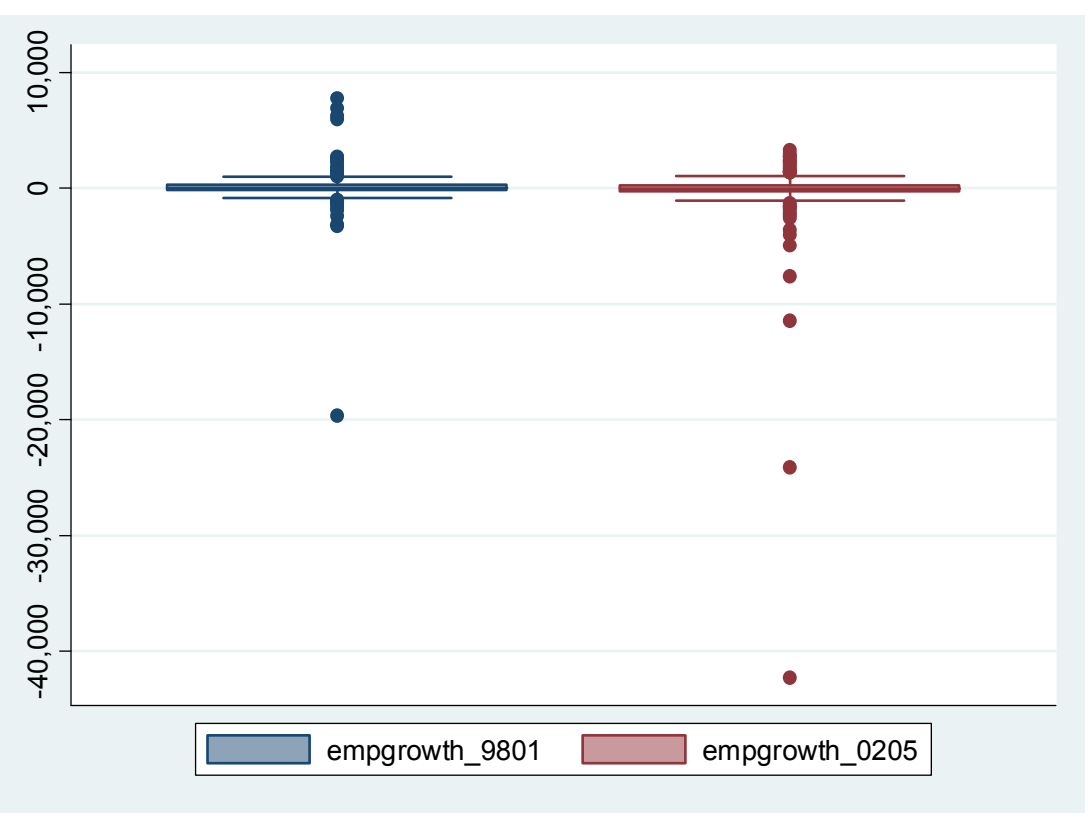

Regional employment growth across periods of investigation

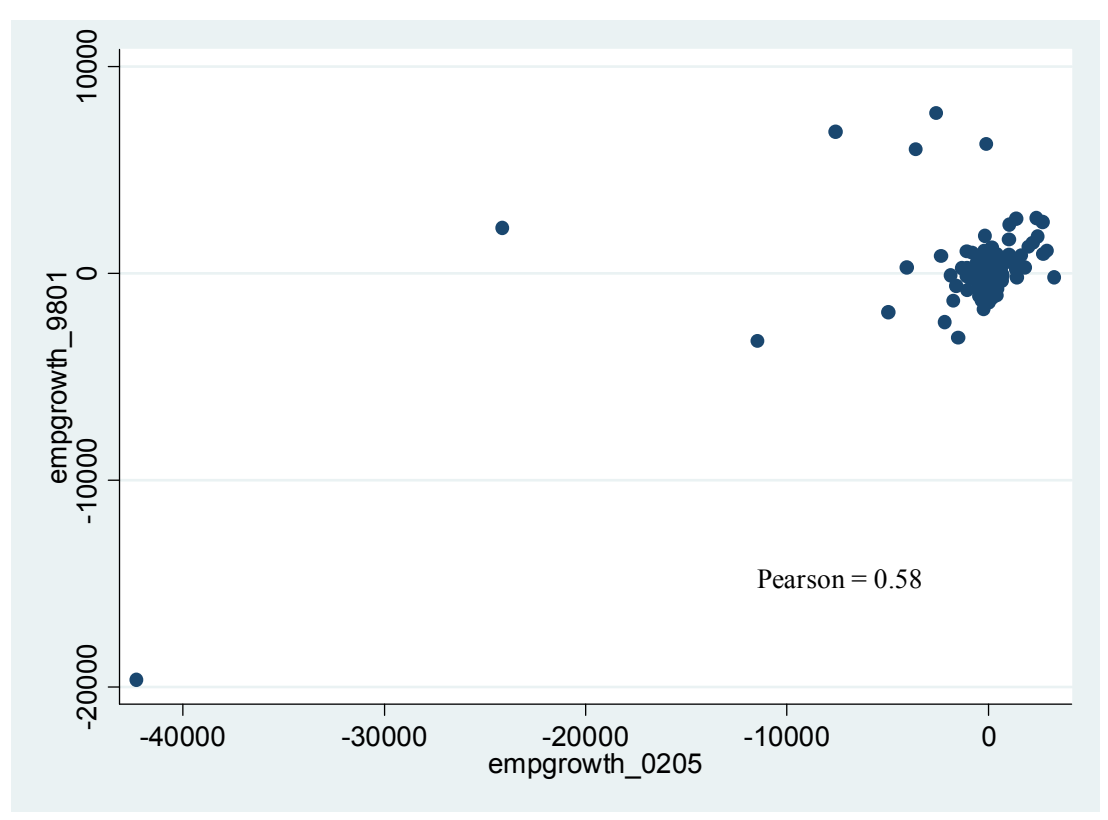


Domestic and foreign employment growth scatter around zero in most of the regions and in both timesets. However, foreign growth varies on a somewhat larger scale than domestic growth: some regions stand out or lag behind more drastically in terms of foreign growth than in domestic growth (Figure 2). Maps in Appendix 2 suggest that regional employment growth stood out in the agglomeration of Budapest in both periods (except the city itself). Foreign companies contributed to growth mainly in those regions that are proximate to Budapest or lie between the capital and the Austrian border. The level of employment has decreased in the peripheral regions of the country.

Figure 2

Foreign versus domestic employment growth in subregions, 1998-2001 and 2002-2005
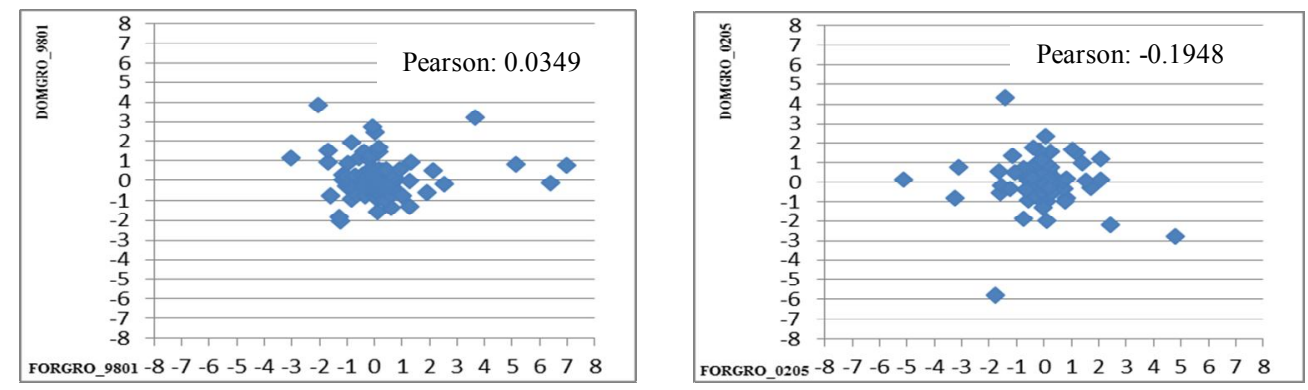

Note: Budapest is left out for reasons of visualization.

\section{Methods}

We follow the seminal work of Frenken et al. (2007) in variable creation. Their argument claims that two co-located firms are technologically unrelated when they don't share twodigit level NACE codes, and might not be able to learn from each other. Two co-located firms are technologically related when they share the same two-digit level NACE codes but don't share the four-digit level NACE code. Related firms might share enough knowledge but are not too proximate, therefore they can not only understand but might also learn new things from each other.

Related variety calculation is as follows. Let pi be the four-digit NACE share of employment and Pg the two-digit level NACE shares of employment that is derived by summing the four-digit shares. Then the variety of economic activity (V) in a region can be phrased as the sum of probabilistic entropy of four-digit level NACE shares (1). This variety can be decomposed to unrelated variety and related variety (2). Unrelated variety (UV) is given as the sum of probabilistic entropy of two-digit level NACE shares (3). Related variety (RV) is the sum of probabilistic entropy of four-digit level NACE shares within each two-digit level NACE shares (5) aggregated at the regional level (4).

$$
\begin{aligned}
& V=\sum_{g=1}^{G} \Sigma_{i \in S_{g}} p_{i} \log _{2}\left(\frac{1}{p_{i}}\right) \\
& V=U V+R V
\end{aligned}
$$




$$
\begin{aligned}
& U V=\sum_{g=1}^{G} P_{g} \log _{2}\left(\frac{1}{p_{g}}\right) \\
& R V=\sum_{g=1}^{G} P_{g} H_{g} \\
& H_{g}=\sum_{i \in S_{g}} \frac{p_{i}}{p_{g}} \log _{2}\left(\frac{1}{p_{i} / g_{g}}\right)
\end{aligned}
$$

As it follows from the above equations, related variety measures the extent to which the technological knowledge base of firms are related in a region. Relatedness is formulated on the base of technological proximity between firms. Other type of proximities into related variety calculation might be straightforward in less developed economies, because institutional gap between dynamic and lagging firms can set back inter-firm learning. The case of post-socialist transition is a good illustration: majority of domestic firms had only limited abilities to learn from the local sites of multinational companies even if they were technologically close to each other (Békés 2005, Grosz 2006).

We address this issue with introducing ownership categories into regional related variety calculations. This needs another level of entropy aggregation but enables us to decompose variety measures into domestic and foreign subsets. Unlike in previous papers, in which related variety was decomposed into subsets of manufacturing and service industries (Mameli et al. 2012) or high-tech manufacturing (Hartog et al. 2012), the introduction of ownership categories requires an additional level of entropy decomposition and a new variable: ownership variety.

Figure 3

Unrelated variety, related variety and firm ownership, a dual economy model

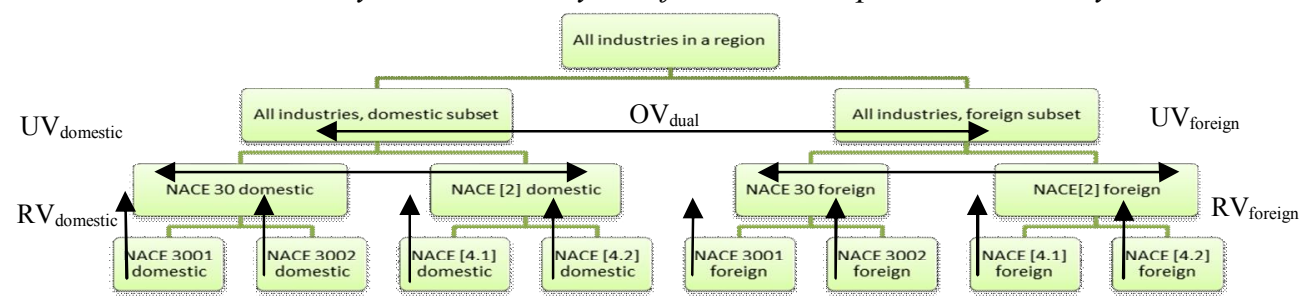

The formulation is visualized in Figure 3. Let poi be the share of employment in industries with four-digit NACE codes combined with ownership categories. Let poi sum up to Pog that is the share of employment in two-digit NACE codes combined with ownership categories. Also, let the sum of Pog be Po, the share of employment in all industries combined with ownership categories. Finally, let ' $d$ ' indicate domestic set of firms and ' $\mathrm{f}$ ' indicate foreign set of firms.

Economic variety measured in the region will be equal to the entropy of the employment distribution of the finest bin structure that is the four-digit NACE code combined with ownership category (6). Then, variety in a region equals with the variety measured in the ownership distribution (OVdual), plus domestic and foreign unrelated varieties (UVD and UVF), plus domestic and foreign related varieties (RVD and RVF). 


$$
\begin{aligned}
& V=\Sigma_{o=f, d} \Sigma_{g=1}^{G} \Sigma_{i \in S_{g}} p_{o i} \log _{2}\left(\frac{1}{p_{o i}}\right) \\
& V=O V_{d w a l}+U V_{d w a l}+R V_{d w a l} \\
& o V_{d w a l}=\Sigma_{o=f, d} P_{o} \log _{2}\left(\frac{1}{p_{0}}\right) \\
& U V_{F, D}=\Sigma_{o=f, d} P_{0} \Sigma_{g=1}^{G} \frac{p_{o g}}{P_{0}} \log _{2}\left(\frac{1}{P_{o g} / p_{0}}\right) \\
& R V_{F, D}=\sum_{o=f, d} P_{o} \Sigma_{g=1}^{G} P_{o g} \sum_{i \in S_{g}} \frac{p_{o i}}{p_{o g}} \log 2\left(\frac{1}{p o t / p_{Q g}}\right)
\end{aligned}
$$

Because Hungarian subregions vary in terms of the size of their economy, we normalized variety measures by the number of employment in the appropriate categories. Accordingly, unrelated variety, related variety, and ownership variety have been divided by number of employment in the region; domestic and foreign unrelated and related variety measures have been divided by the number of employment in the respective subset in the region.

\section{Results}

According to a two-way scatter plot, Hungarian regional employment growth does not seem to be determined by related variety of economic activity in the region (Figure 4). However, one might observe a widening gap between growing and declining regions as related variety increases. Preliminary findings reflect on this issue, and the directions for further work are set as follows.

Related variety and employment growth

Figure 4

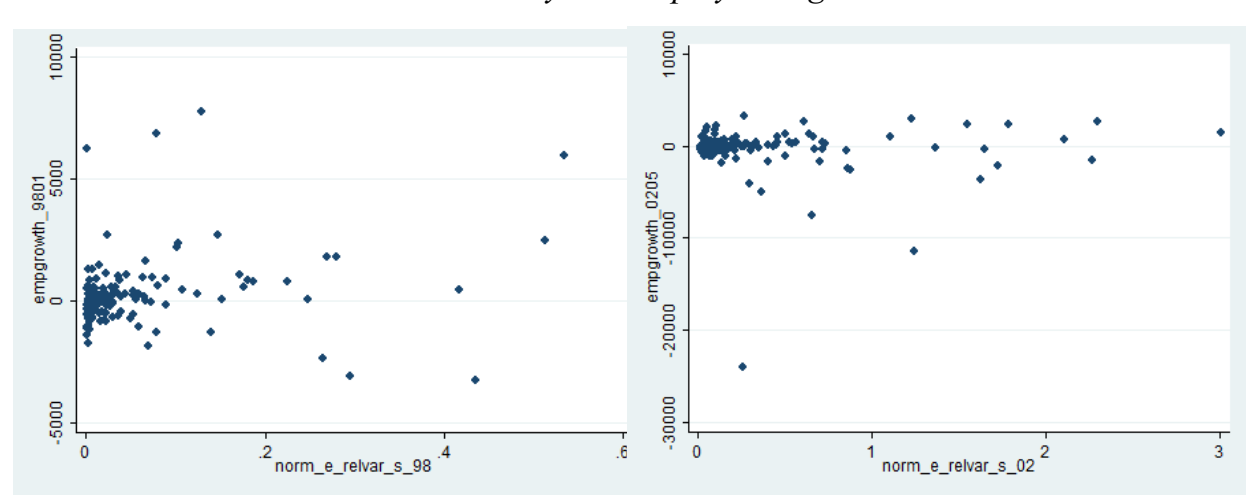

The variables created with the methods above are tested in linear regression with heteroskedasticity-robust standard errors in which employment growth is the dependent variable. The distinct time periods are handled separately and we illustrate a reverse effect of explanatory variables in declining and growing regions. As a next step we look 
at the effect of domestic and foreign related variety on employment growth. Finally, domestic and foreign employment growth will be analysed.

Pearson correlation values in Table 2 indicate high level of association between several variables in both timesets. For example, EMPGRO_F 9801 and EMPGRO_D_0205 correlate on a very high degree with the respected EMPGRO variables. Correlation values are also too high among few pairs of variety measures, namely UNRELVAR_98 and UV_D_98, just as between RELVAR_98, RV_D_98, and RV_F_98. Therefore, classic variety measures and variety measures decomposed to domestic and foreign subsets cannot be tested together, in order to avoid multicollinearity of explanatory variables.

A variety of control variables are introduced to the models (VIF values remains below 10 in all cases); for description of control variables see Appendix 3. Budapest is left out when looking at separate set of growing and declining regions because the capital is an extreme outlier in both of our time periods. County dummies are used in order to capture region-specific effects.

Table 2

Pearson correlation values, 1998 and 2002

\begin{tabular}{|c|c|c|c|c|c|c|c|c|c|c|}
\hline 1998 & & 1 & 2 & 3 & 4 & 5 & 6 & 7 & 8 & 9 \\
\hline 1 & EMPGRO_98-01 & 1.0000 & & & & & & & & \\
\hline 2 & EMPGRO_F_98-01 & 0.9335 & 1.0000 & & & & & & & \\
\hline 3 & EMPGRO D 98-01 & 0.4045 & 0.0498 & 1.0000 & & & & & & \\
\hline 4 & UNRELVAR_98 & 0.0444 & -0.0115 & 0.1529 & 1.0000 & & & & & \\
\hline 5 & RELVAR_98 & -0.7336 & -0.8004 & -0.0019 & 0.0582 & 1.0000 & & & & \\
\hline 6 & OV_dual_98 & 0.0497 & -0.0552 & 0.2792 & 0.4523 & 0.1212 & 1.0000 & & & \\
\hline 7 & UV_D_98 & 0.0315 & -0.0061 & 0.1032 & 0.7755 & 0.0517 & 0.4290 & 1.0000 & & \\
\hline 8 & RV_D_98 & -0.7397 & -0.8006 & -0.0185 & 0.0784 & 0.9953 & 0.1165 & 0.1074 & 1.0000 & \\
\hline 9 & UV_F_98 & 0.0006 & 0.0040 & -0.0085 & 0.2476 & -0.0174 & -0.2537 & 0.1914 & -0.0099 & 1.0000 \\
\hline 10 & RV_F_98 & -0.6565 & -0.7093 & -0.0196 & 0.0917 & 0.8766 & 0.0728 & 0.1827 & 0.8903 & 0.0101 \\
\hline 2002 & & 11 & 12 & 13 & 14 & 15 & 16 & 17 & 18 & 19 \\
\hline 11 & EMPGRO_02-05 & 1.0000 & & & & & & & & \\
\hline 12 & EMPGRO_F_02-05 & 0.3253 & 1.0000 & & & & & & & \\
\hline 13 & EMPGRO_D_02-05 & 0.9585 & 0.0423 & 1.0000 & & & & & & \\
\hline 14 & UNRELVAR_02 & 0.1184 & 0.0271 & 0.1169 & 1.0000 & & & & & \\
\hline 15 & RELVAR_02 & -0.8011 & -0.2226 & -0.7793 & 0.0641 & 1.0000 & & & & \\
\hline 16 & OV_dual_02 & 0.0007 & -0.1894 & 0.0578 & 0.1695 & 0.1048 & 1.0000 & & & \\
\hline 17 & UV_D_02 & 0.0424 & -0.0643 & 0.0642 & 0.7596 & 0.0794 & 0.4103 & 1.0000 & & \\
\hline 18 & RV_D_02 & -0.7974 & -0.2585 & -0.7646 & 0.0771 & 0.9920 & 0.1240 & 0.1185 & 1.0000 & \\
\hline 19 & UV_F_02 & 0.0264 & 0.0294 & 0.0190 & 0.1507 & -0.0254 & -0.3262 & 0.1134 & -0.0247 & 1.0000 \\
\hline 20 & RV_F_02 & 0.0021 & -0.0092 & 0.0050 & 0.3923 & 0.0655 & 0.1445 & 0.4931 & 0.0570 & 0.0798 \\
\hline
\end{tabular}




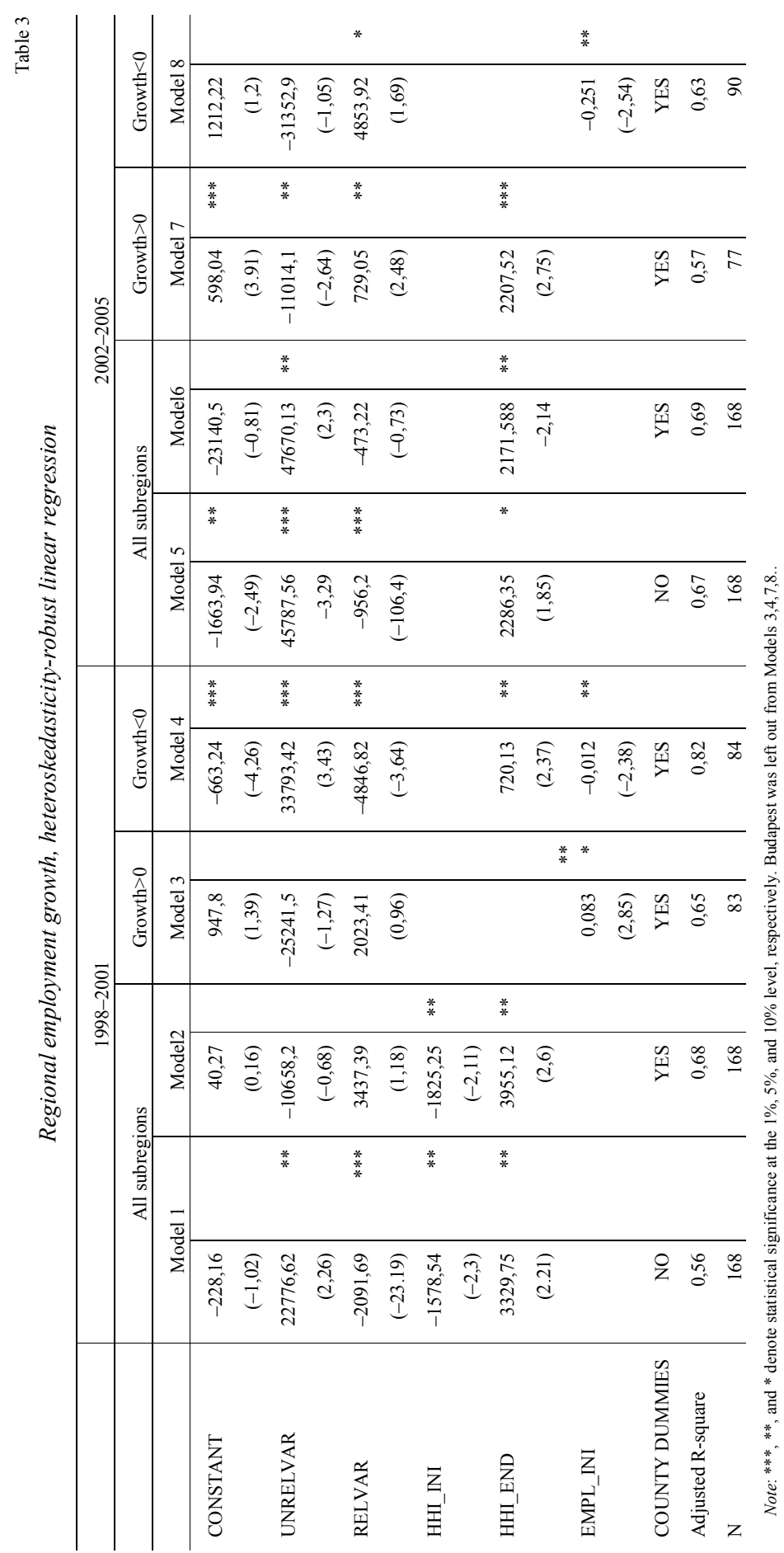


Table 3 summarizes findings of the original related variety calculation (Frenken et al 2007); unrelated variety is calculated by (3) and related variety is formulated by (4) and (5). Interestingly, both Model 1 and Model 5 attribute a significant positive effect to unrelated variety and a significant negative effect to related variety in influencing regional employment growth. These happen to be controversial to what one expects because unrelated variety -being a measure of diversity- is thought to induce a portfolio effect. The higher the unrelated variety the more resistance against external shocks in the region; unrelated variety is expected to reduce the decline. On the other hand, related variety -being a measure of local learning capacities- is expected to enhance regional growth. Although the unexpected sign disappears when county dummies are introduced into the model in the 1998-2001 period (Model 2), unrelated variety still has a significant negative effect on growth in the 2002-2005 period (Model 6). In sum, we don't find a clear effect of related variety -that accords with previous findings in the literature- on regional growth in Hungary.

Our related idea, that merits and needs further efforts to prove in upcoming papers, is that growing and declining regions of transition economies might differ regarding the effect of related variety. In our case, inter-firm learning and technological relatedness is beneficial in those regions that could cope with post-socialist transformation. However, a large number of regions could not break out from the path they had been locked into previously and therefore technological relatedness might be another burden for them. In other words, related variety might even enhance the lag of these latter regions that did not meet the challenges of transition because local learning occurs among uncompetitive industries that lock the region into a declining path. Preliminary results in Table 3 support the idea; however, further work is needed for a detailed demonstration.

Related variety enhances growth in rising regions over the 2002-2005 period and also eases the drop of employment in lagging ones (Model 7 and Model 8). However, related variety had a negative effect on growth in declining regions over 1998-2001 indicating that it speeded up decline in backsliding regions. In our understanding, these results imply that technological relatedness and local learning have a dual effect in Hungary. Furthermore, these effects might change over time, which will have to be investigated over a longer timescale.

One might also argue that unrelated variety performs a sort of portfolio effect as proposed by Frenken et al (2007), because the higher unrelated variety the slower employment drop in sinking regions. This suggests that regions with a relatively diversified economy suffer less from path-dependent recession than regions with a more specialized economy. Accordingly, unrelated variety eases employment loss in regions that drop behind over the 1998-2001 period (Model 4), but also hinders employment growth in prospering regions in 2002-2005 (Model 7). 


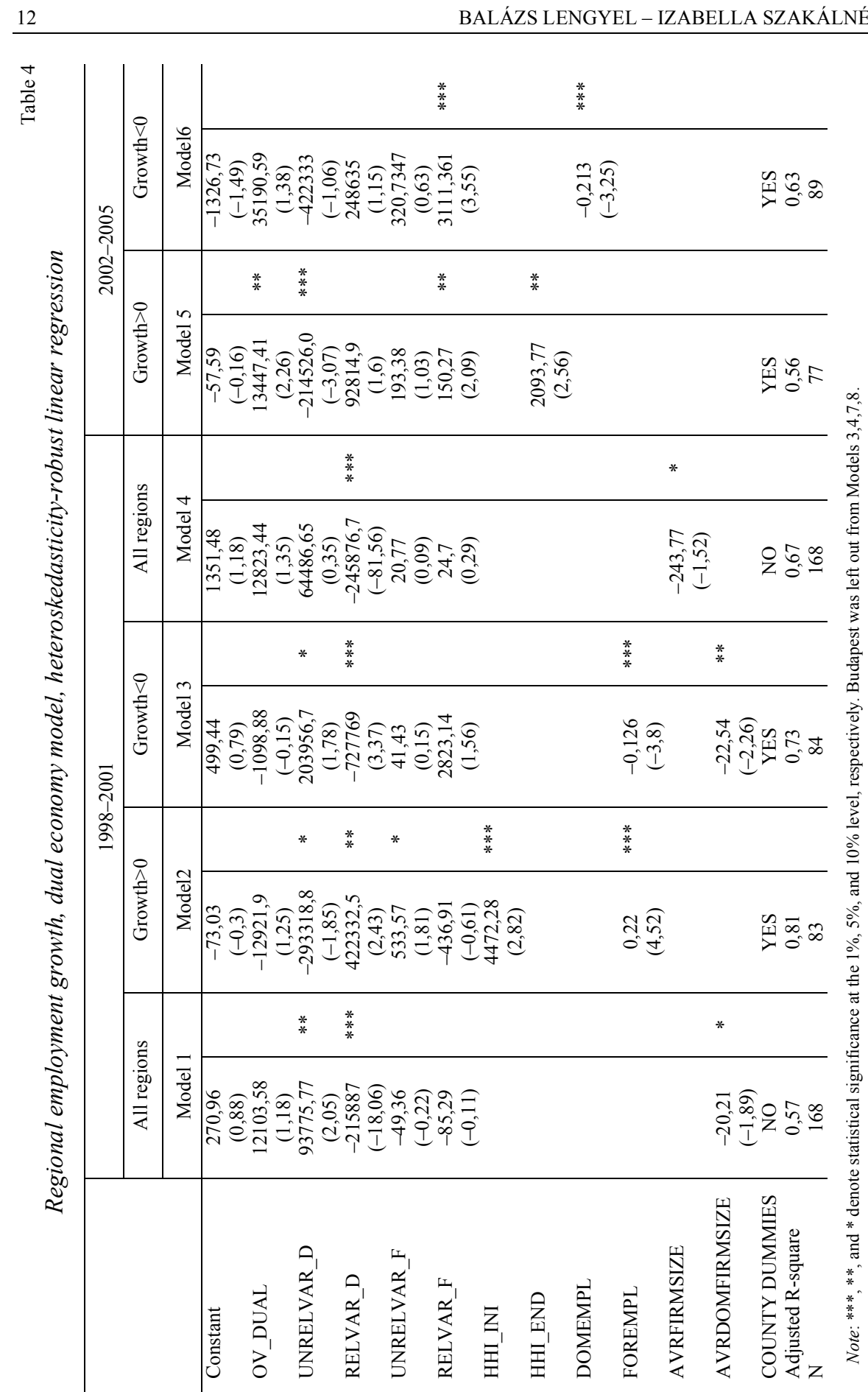


These first findings remain unchanged when unrelated and related varieties are decomposed into domestic and foreign subsets (Table 4). Note that the normalization process (described in Section 4) enables us to compare the effect of domestic and foreign populations even if foreign employment is minor compared to domestic employment in many subregions. Linear regressions with heteroskedasticity-robust standard errors in Table 4 suggest that regional employment growth is mainly affected by technological relatedness in the domestic subset of companies in the 1998-2001 period. Inter-firm learning opportunities among domestic companies might speed up regional growth (Model 2) but also has widened the lag of declining regions (Model 3). Technological relatedness among foreign firms has a significant positive effect on growth over 2002-2005, whereas no such effect was found in the 1998-2001 period.

Regional economies might have evolved over the transition period in a complex way in terms of how domestic and foreign-owned firms have been involved in local learning. Technological relatedness among domestic companies could have widened the gap between dynamic and declining regions due to the lock-in phenomenon that we described earlier. The economy has probably developed into a stage, in which relatedness of colocated domestic companies have influenced regional employment growth in all regions regardless of their previous industry structure. However, we have not found a significant effect of domestic related variety in the 2002-2005 period. On the other hand, local learning among co-located foreign-owned companies might have become crucial factor for regional employment growth. This issue merits a deeper analysis, in our opinion, in which the whole transition period shall be investigated by further papers.

The last insight addresses the cross-effect of related variety of the decomposed sets on domestic and foreign employment growth separately (Table 5). Interestingly, preliminary findings imply that relatedness among foreign firms remains unimportant for both domestic and foreign employment growth. On the other hand, relatedness among domestic companies favoured foreign employment growth in the 1998-2001 period, while domestic unrelated variety hindered foreign growth significantly. One might argue that foreign growth in Hungary does not depend on local relatedness, because foreign companies compete and co-operate not on the local level and their strategies are developed in distant headquarters. However, foreign firms might also benefit from local inter-firm learning and new relatedness measures -that capture relatedness between foreign and domestic subsets- might provide new insights to this issue.

Domestic employment growth is affected by domestic unrelated variety and domestic related variety in a similar manner as compared to the full set of firms. Unrelated variety hinders growth and related variety speeds up growth. Ownership variety also has a positive significant effect on regional employment growth in domestic firms. Since this latter variable is a simple probabilistic entropy measure of employment distribution in two categories, its' positive impact on growth implies that the closer domestic employment to foreign employment in absolute values the higher domestic growth. Thus, our result confirms previous findings that domestic employment growth is high in those regions where foreign employment is relatively also high. 


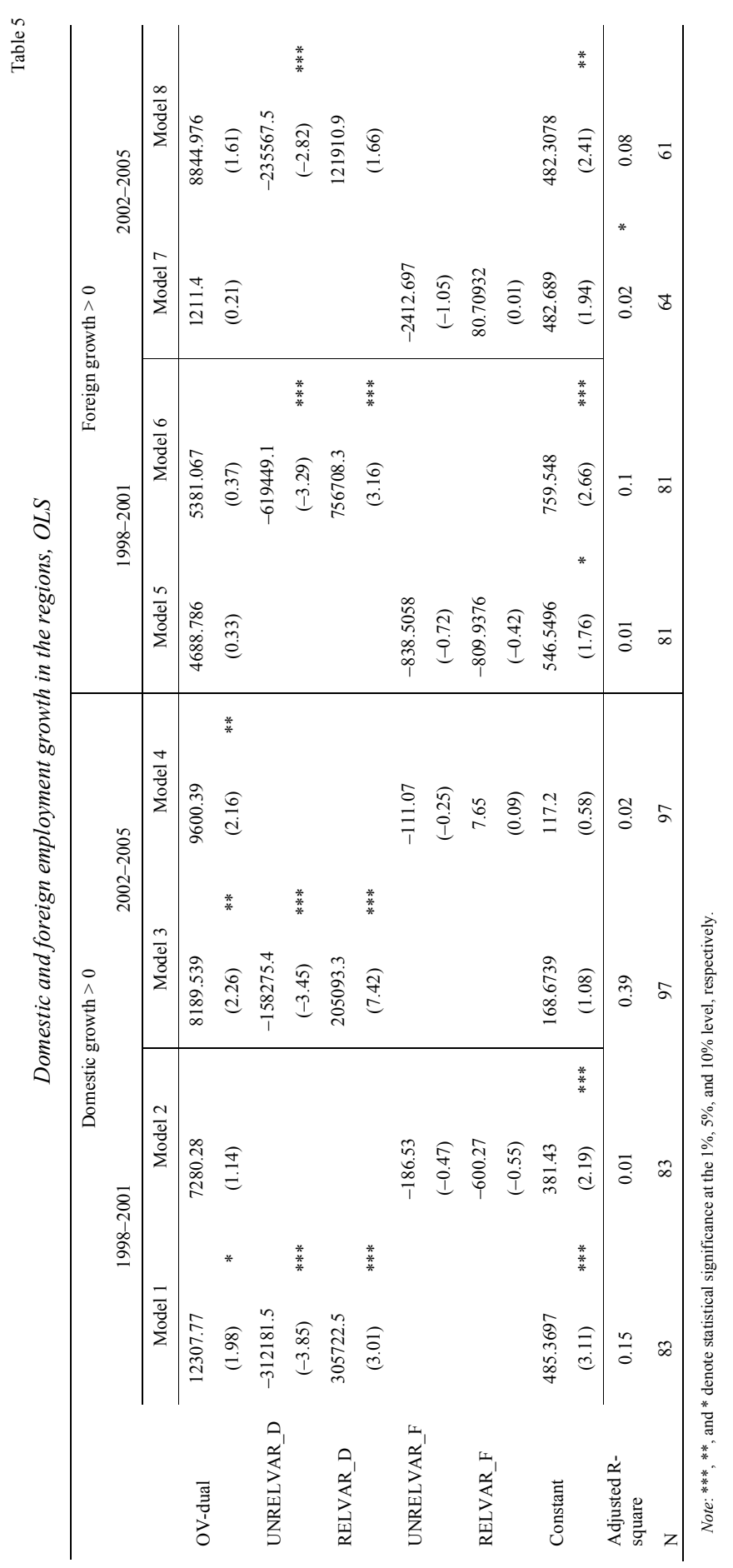




\section{Discussion}

In this paper we have analysed the role of unrelated variety and related variety in Hungary over the 1998-2005 period. Our first special focus was a distinction between regional decline and regional growth. Second, we decomposed the classic variety measures into subsets of domestic and foreign firms.

Our first findings suggest that related variety in a region has a dual effect in regional development over post-socialist transition. Technological relatedness increases employment growth in those regions that could cope with new challenges of market economy because it creates learning opportunities among co-located firms that might lead to innovative outputs. However, related variety also speeds up employment decline in those regions that could not compete on the global economy. These regions might be locked into downhill paths, in which technological relatedness among uncompetitive industries is another obstacle. Future research on a longer timescale data shall pay extra attention to this phenomenon and upcoming papers shall focus on how the effect of related variety changes over time in a transition economy.

The second finding concerns technological relatedness in the domestic and foreignowned subsets. While domestic related variety have predominantly influenced regional growth in the first half of the investigated period, technological relatedness among colocated foreign firms became important in the second half. A possible reason for this pattern is that the dual economic structure -which we usually talk about regarding Hungarian regional development- changes over time and foreign firms might become more integrated into the local texture of the economy at the later stages of the transition than initially. Foreign employment growth was positively affected by domestic related variety, which is a sign of cross-effects. Therefore, future papers will explore foreigndomestic relations in more details. For example, it is possible do re-organize the dual economy model of related variety calculations and introduce ownership categories on a lower level of aggregation (e.g. at two-digit or four-digit NACE code levels). These new models of decomposition might explain domestic-foreign relatedness better than the dual economy model presented in this paper. Also, other type of data (e.g. international trade at company level) might capture foreign-domestic proximities better than employment distribution.

\section{REFERENCES}

Békés, G. (2005): Location of manufacturing FDI in Hungary: how important are inter-company relationships? MNB Working Paper Series No. 2005/7.

Boschma, R. A. (2005) Proximity and innovation. A critical assessment Regional Studies 39 (1): 61-74.

Farkas, P. (2000): The Effects of Foreign Direct Investment on R\&D and Innovation in Hungary. IWE Working Papers No. 108. Institute for World Economics, Hungarian Academy of Sciences.

Frenken, K.,-Van Oort, F.G.-Verburg, T. (2007) Related variety, unrelated variety and regional economic growth. Regional Studies,41(5): 685-697.

Glaeser, E.-Kallal, H. D.-Scheinkman, J. D.-Shleifer, A. (1992): Growth in Cities. Journal of Political Economy 100(6): 1126-1152.

Grosz, A. (2006): Clusterization Processes in the Automotive Industry, Discussion Papers No. 52, Centre for Regional Studies, Hungarian Academy of Sciences. 
Halpern, L.- Muraközy, B. (2007) :Does distance matter in spillover? Economics of Transition 15, pp. 781805 .

Hartog, M.-Boschma, R. -Sotarauta, M. (2012):The impact of related variety on regional employment growth in Finland 1993-2006: High-tech versus medium/low-tech. Industry and Innovation 19(6): 459476.

Hungarian Central Statistical Office (2007) National Accounts of Hungary, 2004-2005. Budapest. Downloaded from: http://portal.ksh.hu/pls/ksh/docs/hun/xftp/idoszaki/monsz/monsz0405.pdf

Iwasaki, I. (2007): Corporate Restructuring and the Role of Foreign Direct Investment in Hungary. In Dallago, B.-Iwasaki, I. (eds): Corporate Restructuring and Governance in Transition Economies. Basingstoke: Palgrave Macmillan, 178-210.

Jacobs, J. (1969): The Economy of Cities. New York: Random House.

Lengyel, B. Cadil, V. (2009): Innovation Policy Challenges in Transition Countries: Foreign Business R\&D in the Czech Republic and Hungary. Transition Studies Review, 16(1): 174188

Lengyel, B. Leydesdorff, L. (2011): Regional Innovation Systems in Hungary: The Failing Synergy at the National Level. Regional Studies, 45(5): 677693.

Lengyel, B., Leydesdorff, L. (2013) Diverse effects of FDI in regional innovation systems: synergy measurement based on complexity theory, and entropy statistics. In press, http://papers.ssrn.com/sol3/papers.cfm?abstract id=2255521

Lengyel, B., Szakálné, K. I. (2013) Regional economic growth in Hungary 1998-2005: what does really matter in clusters? In Press. http://papers.ssrn.com/sol3/papers.cfm?abstract id=2303748

Lengyel, I. (2003) The pyramid model: enhancing regional competitiveness in Hungary. Acta Economica, 53, 4: 323-342.

Lux, G. (2009) Divergent patterns of adaptation among Central European Old Industrial Regions. European Spatial Research and Policy 1, pp. 145-157.

Mameli, F., Iammarino, S., Boschma, R. (2012), Regional variety and employment growth in Italian labour market areas: services versus manufacturing industries, Papers in Evolutionary Economic Geography 12.03, Utrecht University

Marshall, A. (1890): Principles of Economics. London: Macmillan.

Porter, M. (2003): The Economic Performance of Regions. Regional Studies, 37(6-7): 549578.

Szanyi, M. (2003): An FDI-Based Development Model for Hungary - New Challenges? IWE Working Paper 141, Institute for World Economics, Hungarian Academy of Sciences.

Szanyi, M. Iwasaki, I. Csizmadia, P. Illésy, M. Makó, Cs. (2011): Cluster Development in Hungary: Searching for a Critical Mass of Business via Cluster Mapping. In Dallago, B. Guglielmetti, C. (eds): Local Economies and Global Competitiveness, Basingstoke: Palgrave Macmillan, 113133.

UNCTAD (2005): World Investment Report 2005: Transnational Corporations and the Internationalization of $R \& D$. New York and Geneva: United Nations.

\section{Acknowledgement}

We acknowledge repeated discussions with Ron A. Boschma and Imre Lengyel. Miklós Szanyi helped us to get access to the data. The work of Balázs Lengyel was supported by the Hungarian Scientific Research Grant (PD 106290) and IBS Research Grant. 
Appendix 1

Number of firms in industries, NACE 2 level

\begin{tabular}{|c|c|c|}
\hline NACE2 & 1998 & 2002 \\
\hline 15 & 2,557 & 4,226 \\
\hline 16 & 7 & 6 \\
\hline 17 & 727 & 1,394 \\
\hline 18 & 1,071 & 2,463 \\
\hline 19 & 348 & 554 \\
\hline 20 & 1,129 & 2,631 \\
\hline 21 & 229 & 495 \\
\hline 22 & 2,363 & 6,14 \\
\hline 23 & 7 & 13 \\
\hline 24 & 501 & 711 \\
\hline 25 & 960 & 1,754 \\
\hline 26 & 676 & 1,48 \\
\hline 27 & 227 & 333 \\
\hline 28 & 2,478 & 5,532 \\
\hline 29 & 1,95 & 3,454 \\
\hline 30 & 131 & 307 \\
\hline 31 & 669 & 1,192 \\
\hline 32 & 486 & 936 \\
\hline 33 & 753 & 1,648 \\
\hline 34 & 221 & 294 \\
\hline 35 & 123 & 263 \\
\hline 36 & 965 & 2,776 \\
\hline 37 & 83 & 211 \\
\hline 40 & 201 & 287 \\
\hline 41 & 214 & 307 \\
\hline 45 & 10,025 & 27,805 \\
\hline 50 & 4,801 & 11,767 \\
\hline 51 & 20,118 & 32,088 \\
\hline 52 & 12,988 & 40,815 \\
\hline 55 & 4,05 & 13,708 \\
\hline 60 & 2,58 & 7,057 \\
\hline 61 & 47 & 104 \\
\hline 62 & 46 & 76 \\
\hline 63 & 1,754 & 3,634 \\
\hline 64 & 315 & 953 \\
\hline 65 & 575 & 797 \\
\hline 66 & 24 & 94 \\
\hline 67 & 532 & 2,801 \\
\hline 70 & 6,334 & 16,879 \\
\hline 71 & 765 & 1,622 \\
\hline 72 & 3,143 & 11,118 \\
\hline 73 & 627 & 1,687 \\
\hline 74 & 17,213 & 50,024 \\
\hline 80 & 833 & 5,203 \\
\hline 85 & 1,523 & 12,03 \\
\hline 90 & 471 & 790 \\
\hline 91 & 439 & 2,519 \\
\hline 92 & 3,051 & 12,012 \\
\hline 93 & 745 & 3,052 \\
\hline
\end{tabular}



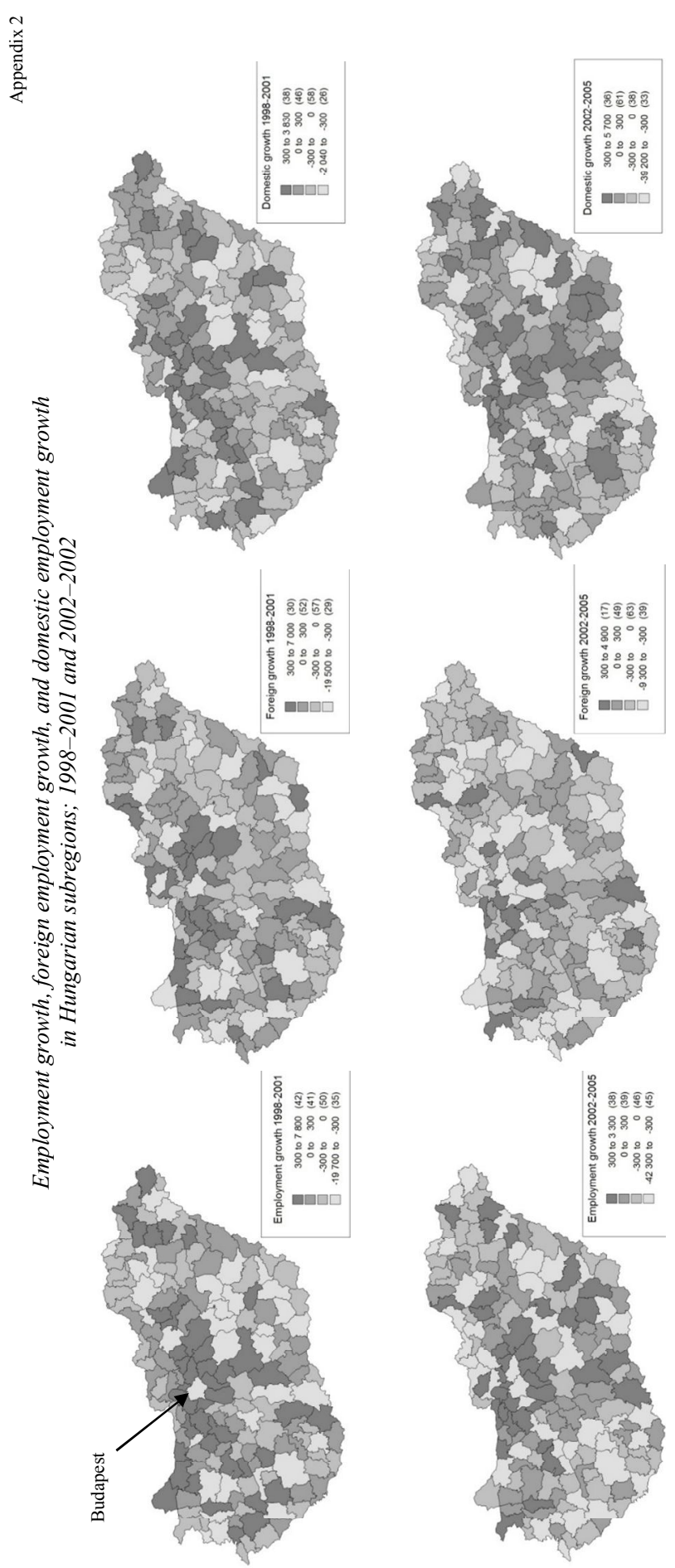


\section{Description and statistics of control variables}

Appendix 3

\begin{tabular}{|c|c|c|c|c|c|c|}
\hline Abbreviation & Description & & Mean & St. Dev. & Min & Max \\
\hline HHI_INI & $\begin{array}{l}\text { Hirschman-Herfindhal } \\
\text { index at the starting point } \\
\text { of our period, calculated } \\
\text { from company-level } \\
\text { market shares. }\end{array}$ & ‘02 & .1044115 & .1210299 & .0061086 & $\begin{array}{l}.8974066 \\
.7810547\end{array}$ \\
\hline HHI_END & $\begin{array}{l}\text { Hirschman-Herfindhal } \\
\text { index at the ending point } \\
\text { of our period, calculated } \\
\text { from company-level } \\
\text { market shares. }\end{array}$ & $\begin{array}{l}' 98 \\
' 02\end{array}$ & $\begin{array}{l}.1298001 \\
.0941696\end{array}$ & $\begin{array}{l}.1388309 \\
.1188845\end{array}$ & $\begin{array}{l}.0093472 \\
.0070743\end{array}$ & $\begin{array}{r}.9825625 \\
.767398\end{array}$ \\
\hline EMPL_INI & $\begin{array}{l}\text { Absolute value of initial } \\
\text { employment level in the } \\
\text { region. }\end{array}$ & $\begin{array}{l}\text { '98 } \\
\text { '02 }\end{array}$ & $\begin{array}{l}10603.96 \\
12457.99\end{array}$ & $\begin{array}{r}55852.08 \\
61352.4\end{array}$ & $\begin{array}{l}172 \\
520\end{array}$ & $\begin{array}{l}720730 \\
789646\end{array}$ \\
\hline DOMEMPL & $\begin{array}{l}\text { Absolute value of initial } \\
\text { domestic employment } \\
\text { level in the region. }\end{array}$ & $\begin{array}{l}' 98 \\
' 02\end{array}$ & $\begin{array}{l}7120.369 \\
9304.613\end{array}$ & $\begin{array}{r}35993 \\
44666.19\end{array}$ & $\begin{array}{l}157 \\
380\end{array}$ & $\begin{array}{l}463912 \\
574023\end{array}$ \\
\hline FOREMPL & $\begin{array}{l}\text { Absolute value of initial } \\
\text { foreign employment level } \\
\text { in the region. }\end{array}$ & $\begin{array}{l}\text { '98 } \\
' 02\end{array}$ & $\begin{array}{l}3483.595 \\
3153.375\end{array}$ & $\begin{array}{r}19934.86 \\
16834.9\end{array}$ & 0 & $\begin{array}{l}256818 \\
215623\end{array}$ \\
\hline AVRFIRMSIZE & $\begin{array}{l}\text { Average number of } \\
\text { employees in firms in the } \\
\text { region. }\end{array}$ & $\begin{array}{l}' 98 \\
' 02\end{array}$ & $\begin{array}{l}511.6148 \\
7.423348\end{array}$ & $\begin{array}{r}4502.682 \\
2.526928\end{array}$ & $\begin{array}{l}4.598214 \\
2.915344\end{array}$ & $\begin{array}{r}41518 \\
14.52036\end{array}$ \\
\hline $\begin{array}{l}\text { AVRDOMFIRMSI } \\
\text { ZE }\end{array}$ & $\begin{array}{l}\text { Average number of } \\
\text { employees in domestic } \\
\text { firms in the region. }\end{array}$ & $\begin{array}{l}' 98 \\
' 02\end{array}$ & $\begin{array}{l}15.00056 \\
252.6752\end{array}$ & $\begin{array}{l}6.982313 \\
3196.234\end{array}$ & $\begin{array}{r}4.90625 \\
2.603261\end{array}$ & $\begin{array}{r}57.17213 \\
41434\end{array}$ \\
\hline
\end{tabular}

